\title{
An Updated Review of Pro- and Anti-Inflammatory Properties of Plasma Lysophosphatidylcholines in the Vascular System
}

\author{
Eva Knuplez ${ }^{1, *(D)}$ and Gunther Marsche ${ }^{1,2, *(D)}$ \\ 1 Division of Pharmacology, Otto Loewi Research Center, Medical University of Graz, 8010 Graz, Austria \\ 2 BioTechMed-Graz, 8010 Graz, Austria \\ * Correspondence: eva.knuplez@medunigraz.at (E.K.); gunther.marsche@medunigraz.at (G.M.); \\ Tel.: +43-385-74115 (E.K.); +43-316-385-74128 (G.M.)
}

Received: 28 May 2020; Accepted: 23 June 2020; Published: 24 June 2020

\begin{abstract}
Lysophosphatidylcholines are a group of bioactive lipids heavily investigated in the context of inflammation and atherosclerosis development. While present in plasma during physiological conditions, their concentration can drastically increase in certain inflammatory states. Lysophosphatidylcholines are widely regarded as potent pro-inflammatory and deleterious mediators, but an increasing number of more recent studies show multiple beneficial properties under various pathological conditions. Many of the discrepancies in the published studies are due to the investigation of different species or mixtures of lysophatidylcholines and the use of supra-physiological concentrations in the absence of serum or other carrier proteins. Furthermore, interpretation of the results is complicated by the rapid metabolism of lysophosphatidylcholine (LPC) in cells and tissues to pro-inflammatory lysophosphatidic acid. Interestingly, most of the recent studies, in contrast to older studies, found lower LPC plasma levels associated with unfavorable disease outcomes. Being the most abundant lysophospholipid in plasma, it is of utmost importance to understand its physiological functions and shed light on the discordant literature connected to its research. LPCs should be recognized as important homeostatic mediators involved in all stages of vascular inflammation. In this review, we want to point out potential pro- and anti-inflammatory activities of lysophospholipids in the vascular system and highlight recent discoveries about the effect of lysophosphatidylcholines on immune cells at the endothelial vascular interface. We will also look at their potential clinical application as biomarkers.
\end{abstract}

Keywords: lysophosphatidylcholine; inflammation; secreted phospholipases; biomarker; bioactive lipids

\section{Introduction}

Formerly known as lysolecithins, elevated plasma levels of lysophosphatidylcholines (LPCs) were discovered in the 1950s in certain pathological conditions and were identified as a metabolic product of snake venom [1,2]. In contrast to phospholipids, LPCs are "cone-shaped", with a polar "head" and a non-polar "tail" and therefore possess detergent-like properties [3]. The geometry of the LPC structure is also determined by the degree of saturation of the acyl chain. Combined, the saturation and length of the acyl chain is detrimental to its biophysical properties as well as its activity [4,5].

In addition to having non-specific membrane effects LPC was also reported to influence cell functions and activation status via binding to cell-specific G-coupled protein receptors (GPCRs) [6,7]. As of today, reports of LPC specifically binding to GPR119 [8], GPR40 (free fatty acid receptor 1) [9], GPR55 [9,10], GPR4 [11] as well as G2A [12] have been published. However, the study that reported binding of LPC to G2A [13] had to be withdrawn, because the authors could not demonstrate 
whether LPCs mediated its effects on cells directly via the receptor or via indirect membrane effects. Moreover, GPR4 was later found to be $\mathrm{pH}$ sensitive (proton-sensing GPCR) and results with LPC could not be reproduced [14-16]. More recent studies support the finding that binding of LPC or its derivates to GPR119, GPR40 and GPR55 induces intracellular calcium mobilization and leads to increased glucose-stimulated insulin secretion in different cell systems $[9,17]$. Interestingly, the authors demonstrated modulation of GPR40, GPR55 and GPR119 receptor binding affinities using phosphorothioate modified endogenous LPC [9]. When LPC was modified with a covalently bound $P$-anisic acid at the $s n-1$ position, this increased its stability and decreased its toxicity showing the potential of LPC modification as a therapeutic option, when enhanced insulin secretion is needed [17].

Concentration of LPC in plasma and body fluids is already high under physiological conditions and reaches 100-300 $\mu \mathrm{M}[5,18]$. LPCs are bound mainly to albumin and to a lesser extent to lipoproteins [19-22]. Inflammation, cell damage and other pathophysiological conditions can profoundly alter the ratio of free to albumin bound LPC through increased production of LPC or decreased plasma levels of albumin [23-25].

Plasma LPCs are bioactive lipid metabolites of phosphatidylcholine, which are mainly produced by the action of secretory phospholipases $\mathrm{A} 2\left(\mathrm{sPLA}_{2}\right)$ after removal of a fatty acid [26]. LPCs are also produced by the action of HDL-associated lecithin-cholesterol acyltransferase in the reverse cholesterol pathway [27], by the action of hepatic [28] and endothelial lipase [29] on lipoproteins as well as during lipoprotein oxidation [30]. The family of sPLA ${ }_{2}$ enzymes contains 10 catalytically active isoforms (IB, IIA, IIC, IID, IIE, IIF, III, V, X), which are differentially expressed in tissues and exhibit unique

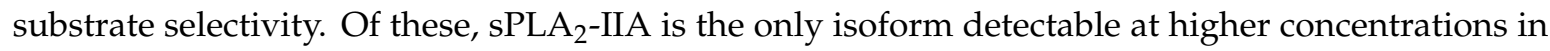
the bloodstream and is particularly elevated during inflammatory processes, triggering production of bioactive mediators of inflammation and resolution of inflammation [31,32]. One of the most well studied sPLA $\mathrm{P}_{2}$ cleavage product beside LPC is arachidonic acid, which can be further converted via enzymatic (cyclooxygenase-I,-II and lipoxygenase) or non-enzymatic (auto-oxidation with reactive oxygen species) metabolism into prostaglandins, lipoxins and resolvins [33].

Interestingly, most of the recent studies, in contrast to older studies, found lower LPC plasma levels associated with unfavorable disease outcomes. Decreased levels of LPC were observed in rheumatoid arthritis [34], diabetes [35], schizophrenia [36], polycystic ovary syndrome [37,38], Alzheimer disease [39,40], pulmonary arterial hypertension [41], aging [42], asthma [43] and liver cirrhosis, where they were associated with increased mortality risk [44].

\section{The Complex Role of LPC in Vascular Inflammation}

\subsection{Postulated Pro-Inflammatory Action of LPC on Vascular Reactivity}

Endothelial cell dysfunction and subsequent changes in vascular reactivity are one of the earliest changes associated with atherosclerotic cardiovascular disease [45]. Oxidized low-density lipoprotein (ox-LDL) modified by the action of secretory phospholipase was found to inhibit endothelium-dependent relaxations [46]. Similar observations were made using free LPC, which was able to produce a defect in endothelium-dependent vasomotor regulation [47]. This could be explained by the finding that both ox-LDL [48] and LPC reduce the production of prostaglandin $\mathrm{PGI}_{2}$ in endothelial cells [49]. Subsequent research showed that reduced nitric oxide (NO) and not $\mathrm{PGI}_{2}$ production in endothelial cells is inhibited and responsible for the defects in vasorelaxation [50,51]. Others describe the involvement of proconstricting prostanoids and superoxide anions in LPC-attenuated vasorelaxation [52]. Not only endothelium-dependent vasorelaxation is reportedly impacted by LPC, but ox-LDL enriched in LPC can also independently cause vasoconstriction [53] or potentiate angiotensin II induced vasoconstriction [54]. It must be noted that ox-LDL consists of a complex mixture of many oxidized lipids and protein oxidation products in addition to LPC. This yields inconsistent results because, as Rao et al. showed [52], the potency as well as the underlying mechanisms of LPC-dependent attenuation of vasorelaxation is heavily dependent on the LPC acyl chain length and degree of saturation. 


\subsection{Postulated Anti-Inflammatory Action of LPCs on Vascular Reactivity}

In contrast to studies mentioned previously, reports of LPC inducing endothelium-dependent relaxation of smooth muscle cells via their non-specific membrane action have been published $[55,56]$. The induction of vasorelaxation was attributed to decreased endothelin-1 release, which acts as a potent vasoconstrictor [57]. Equally important was the finding that LPC induces cyclooxygenase-2 and endothelial nitric oxide synthase (eNOS) expression in endothelial cells, both of which can have vasoprotective effects either via production of prostacyclin or nitric oxide [58-61]. These observations indicate that LPC contributes to NO and endothelin-1 net balance, which regulates local vascular tone [62].

A recent study provided evidence that high-density lipoprotein (HDL) enriched with LPC (endothelial lipase modified HDL) increases eNOS activity by enriching the plasma membrane eNOS pool [63]. Moreover, LPC increased antioxidative capacity of HDL and protected LDL from oxidation [64]. In fact, contrarily to above mentioned older studies [48,49], in more recent studies LPC was shown to induce PGI $_{2}$ production in endothelial cells [65]. These reports were confirmed in vivo, where it was shown that vascular relaxation induced by LPC administration was dependent on functional and morphological integrity of the vascular wall [66]. Moreover, LPC administration increased coronary blood flow as well as decreased mean arterial pressure and total vascular resistance in rabbit [67]. An overview of potential anti-inflammatory actions of LPC at the vessel-endothelial interface is shown in Figure 1.

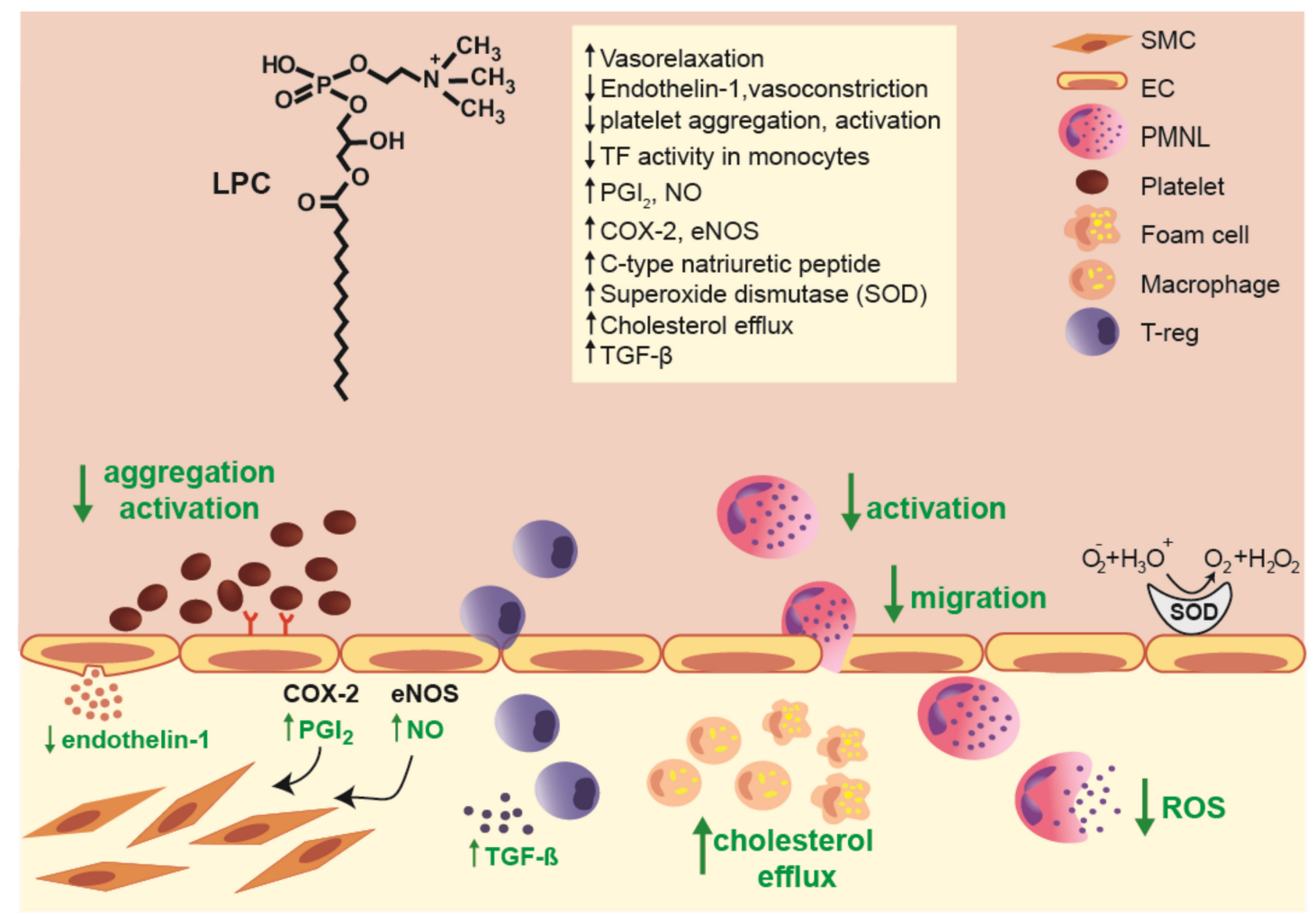

Figure 1. Overview of multiple anti-inflammatory effects of lysophosphatidylcholines (LPCs) at the vessel-endothelial interface. Abbreviations: COX-2, cyclooxygenase-2; EC, endothelial cell; eNOS, endothelial nitric oxide synthase; NO, nitric oxide; PMNL, polymorphonuclear leukocytes; ROS, reactive oxygen species; SMC, smooth muscle cells; TF, tissue factor; TGF- $\beta$, transforming growth factor beta; T-reg, T regulatory cells. 


\subsection{Investigating the Effects of LPCS on Immune Cells Involved in Vascular Inflammation}

Immune cells are involved in all stages of atherosclerosis and are a major contributor of atherosclerosis progression [68,69]. While immune cells are normally present in the vascular system, their quantity and activation status are increased in atherosclerotic lesions. Through their action and production of cytokines they are able to alter the endothelial inflammatory phenotype and contribute to structural instability of atherosclerotic plaques [68,70]. Older studies reported that LPCs may directly contribute to immune cell infiltration during vascular inflammation by increasing the expression of adhesion molecules such as intercellular adhesion molecule 1 (ICAM-1) [71,72], vascular cell adhesion protein 1 (VCAM-1) [73] or P-selectin [74], the expression of damage associated molecular patterns (DAMP) and MHC-II receptors [75] and by production of chemokines such as monocyte chemoattractant protein (MCP-1), IL-8, and Chemokine (C-C motif) ligand 5 (CCL5), also known as RANTES from endothelial cells. Furthermore, LPC was found to act as a strong chemoattractant for monocytes [76,77], T cells [78] as well as natural killer (NK) cells [79], attracting them to sites of inflammation.

Similar to reports investigating the effects of LPC on vascular reactivity and endothelial activation, there are also contradictory reports on the effect of LPC on immune cells.

\subsubsection{Effects of LPCs on Innate Immune Cells}

Innate immune cells mainly consisting of monocytes and macrophages are the major players involved in the initiation and progression of vascular inflammation [80]. Studies performed on monocytes and macrophages on one hand show that LPC is able to activate macrophages, increase their phagocytic activity in the presence of $\mathrm{T}$ lymphocytes [81] and polarize them towards an M1-like phenotype [82]. Moreover, LPC was found to promote the release of arachidonic acid from monocytes [83] and regulate genes in the cholesterol synthesis pathway [84]. On the other hand, LPC was found to abrogate IL-6 release following lipopolysaccharide (LPS) stimulation [85] as well as to down-regulate platelet-activating factor (PAF) receptor expression and LPS-induced NF- $\mathrm{KB}$ translocation to the nucleus in monocytes [86]. A possible explanation for the seemingly confounding reports in monocytes was published by Carneiro et all where they proposed LPC serves as a dual-activity ligand molecule. LPC directly activates toll-like receptor (TLR) 4 and TLR-2-1 receptors in the absence of classical TLR ligands; however it inhibits TLR-mediated signaling in the presence of classical TLR ligands thereby acting as anti-inflammatory [87]. The surprising discovery of LPC mediated cholesterol efflux from cholesterol-laden macrophages-a well-known atheroprotective function of HDL-further suggested potent anti-atherogenic effects of LPC [88,89].

The granulocyte population of innate cells consisting of mast cells, neutrophils and eosinophils represents a smaller fraction of infiltrating immune cells during vascular inflammation [80]. However, their secreted granules contain factors capable of potentiating tissue damage and inflammation and proteases capable of modifying the surrounding extracellular matrix and locally deposited lipoproteins $[90,91]$. Moreover, it was shown that activated neutrophils and eosinophils form extracellular traps in the vessel wall, which are implicated in the clinical severity of the coronary lesion $[90,92]$.

According to older studies performed in the 1980s, LPCs enhance the oxidative burst and reactive oxygen production in neutrophils [93]. However, the ability of LPC to prime neutrophils is heavily dependent on the length of the acyl chain of the molecule [93]. A more recent study performed by Lin et al. demonstrated that the most abundant LPC species in plasma (16:0, 18:0 and 18:1) in fact inhibit reactive oxygen production and activation of neutrophils. Furthermore, they demonstrated that the observed effect markedly varies on the solvent used to prepare LPC. Additionally, they demonstrated the anti-inflammatory effects of LPC in an ex vivo lung perfusion model where LPC prevented lung vascular injury mediated by neutrophils [94]. Curcic et al. likewise demonstrated that LPCs (16:0, 18:0 and 18:1) potently and rapidly inhibit neutrophil effector responses [95]. Similar results could be observed using eosinophils, where some studies found LPCs to increase cell migration [96] and 
adhesion [97]. Others, using physiological LPC-albumin complexes, discovered the ability of saturated LPCs to inhibit the activation and migration of isolated human eosinophils in vitro and in vivo [98]. LPCs were also found to either potentiate mast cell activation and secretion [99] or to inhibit histamine release, serving as a endogenous membrane stabilizers [100]. Altogether, the multiple LPC-induced pro- or anti-inflammatory activities on immune cells make it difficult to draw clear conclusions at the moment. However, it appears that addition of LPC as physiological LPC-albumin or LPC-HDL complexes, as performed in more recent studies, in general demonstrate anti-inflammatory properties.

\subsubsection{The Proposed Roles of LPC on the Adaptive Immune System}

Adaptive immunity is defined by the presence of lymphocytes, consisting of T-cells and immunoregulatory cytokines, majorly influencing inflammation in the vascular wall and atherosclerosis disease activity and progression [101]. The involvement of $\mathrm{T}$ cells in atherosclerosis is supported by the discoveries that approximately $10 \%$ of $\mathrm{T}$ lymphocytes isolated from atherosclerotic lesions recognize oxidized LDL in an MHC-II class restricted manner [102] and that early lesions isolated from apolipoprotein E deficient mice show evidence of clonal T-cell expansion [103]. LPC, in contrast to other lysophospholipids, was found to specifically potentiate the activation of $\mathrm{T}$ lymphocytes, while having no effect on resting cells [104]. ROS production and chemokine receptor expression in human Jurkat $\mathrm{T}$ cells were similarly significantly increased upon LPC addition $[105,106]$. Furthermore, LPC enhanced IFN- $\gamma$ secretion and gene expression in $\mathrm{CD}^{+}$and $\mathrm{CD} 8^{+} \mathrm{T}$ cells as well as increased CD40L and CXCR4 expression in CD4 ${ }^{+} \mathrm{T}$ cells [107-109]. This enhanced activation of effector T cells, exhibited by increased OX40-Ligand (OX40L) and IFN- $\gamma$ secretion by LPC may augment the inflammatory response in atherosclerotic lesions.

On the other hand, LPC enhances the suppressive function of human naturally occurring regulatory T cells through TGF- $\beta$ production [110]. Several studies have demonstrated the atheroprotective role of $\mathrm{T}$ regulatory cells in murine models of atherosclerosis [111,112]. Moreover, the anti-inflammatory effects of TGF- $\beta$ are supported by human clinical data showing patients with advanced atherosclerosis have less active TGF- $\beta$ [113] and in experimental models, where application of anti-TGF- $\beta$ blocking antibodies accelerated the development of atherosclerotic lesions [114]. Altogether LPC involvement in T-cell mediated inflammation is yet unclear. From augmenting the activation of effector T cells in the early stages of inflammation to aiding in immunosuppression by T regulatory cell activation, LPC might serve as an endogenous homeostatic factor potentiating specific T-cell responses as needed.

\subsection{Additional Anti-Inflammatory Effects of LPC in Vascular Inflammation and Atherosclerosis Development}

When activated, platelets adhere to the endothelial monolayer and set a variety of inflammatory mediators, promote atherogenesis and increase vascular inflammation $[115,116]$. Reports of LPC possessing potent anti-aggregatory effects on platelets originate from the 1960s [117]. More recent studies confirm that modification of lipoproteins by secretory phospholipases inhibit platelet activation and aggregation and identify LPC as playing an essential role in the observed effects $[118,119]$. Furthermore, different LPC species were found to dose-dependently inhibit platelet aggregation induced by different agonists [119]. Coagulation is a complex process [120] and LPC was found not just to inhibit platelet aggregation, but also to reduce tissue factor activity in monocytes thereby attenuating coagulation in atherosclerotic lesions [121]. Additional vasoprotective and anti-inflammatory effects of LPC include increased expression of extracellular superoxide dismutase, which is important for antioxidant capacity of vascular walls [122] and of C-type natriuretic peptide, which inhibits the migration and proliferation of vascular smooth muscle cells [123]. Finally, the ability of LPC to bind $\mathrm{C}$-reactive protein (CRP) and therefore suppress its pro-atherogenic effect on macrophages and delay the progression of atherosclerosis was reported [124]. A list of potentially beneficial effects of LPCs in relation to vascular inflammation and tumor formation is given in Table 1. 
Table 1. Proposed favorable functions of lysophosphatidylcholines related to vascular inflammation and tumor development.

\begin{tabular}{|c|c|c|}
\hline Function/Action & Tissue/Cell Type Studied & LPC Species Examined \\
\hline $\begin{array}{l}\text { Inhibition of platelet aggregation } \\
\qquad[118,119]\end{array}$ & platelets & $\begin{array}{c}\text { Mixture [118]; } \\
\text { LPC 16:0, LPC 18:0, LPC 18:1, LPC } \\
\text { 18:2 [119] }\end{array}$ \\
\hline $\begin{array}{l}\text { Decreased tissue factor activity } \\
\text { and NF-kB expression [121]; } \\
\text { Increased expression of } \\
\text { extracellular superoxide } \\
\text { dismutase [122]; } \\
\text { Suppression of IL-6 release } \\
\text { following lipopolysaccharide } \\
\text { (LPS) stimulation [85]; } \\
\text { Down-regulation of platelet } \\
\text { activating factor (PAF) receptor } \\
\text { expression and NF- } \mathrm{kB} \\
\text { translocation to nucleus [86]; } \\
\text { Decreased high-mobility group } \\
\text { protein } 1 \text { (HMGB-1) } \\
\text { production [125] }\end{array}$ & monocytes & $\begin{array}{l}\text { LPC 16:0 [121]; } \\
\text { Mixture [122]; } \\
\text { Not listed [85]; } \\
\text { Mixture [86]; } \\
\text { LPC 18:0 [125] }\end{array}$ \\
\hline $\begin{array}{c}\text { Increase in cholesterol } \\
\text { efflux }[88,89]\end{array}$ & macrophage foam cells & $\begin{array}{c}\text { LPC 14:0, LPC 16:0, LPC 18:0 [88]; } \\
\text { Not listed [89] }\end{array}$ \\
\hline $\begin{array}{c}\text { Vascular smooth muscle } \\
\text { relaxation }[55,56] ; \\
\text { Decrease in mean arterial pressure } \\
\text { and coronary, renal and total } \\
\text { vascular resistance [67] }\end{array}$ & $\begin{array}{c}\text { rabbit aortic strip }[55,56] \\
\text { in vivo application in rabbit [67] }\end{array}$ & $\begin{array}{c}\text { Mixture [55]; } \\
\text { LPC 10:0, LPC 14:0, LPC 16:0, LPC } \\
\text { 18:0, LPC 18:1 [56]; } \\
\text { Not listed [67] }\end{array}$ \\
\hline $\begin{array}{c}\text { Suppression of endothelin-1 } \\
\text { secretion [57]; } \\
\text { Increased prostacyclin production } \\
{[58,65] \text {; Increase in NO }} \\
\text { production }[60,61]\end{array}$ & endothelial cells & $\begin{array}{c}\text { LPC 16:0 [57,58,60]; } \\
\text { LPC 16:0, LPC 18:1, LPC 20:4 [65]; } \\
\text { Not listed [61] }\end{array}$ \\
\hline $\begin{array}{l}\text { Increased C-type natriuretic } \\
\text { peptide expression [123] }\end{array}$ & vascular smooth muscle cells & Mixture \\
\hline $\begin{array}{l}\text { Promotion of dendritic cell } \\
\text { maturation [126]; } \\
\text { Reduction of cell motility and } \\
\text { adhesion [127] }\end{array}$ & dendritic cells & $\begin{array}{l}\text { Mixture [126]; } \\
\text { LPC 18:0 [127] }\end{array}$ \\
\hline $\begin{array}{c}\text { (Potentiated) T-cell } \\
\text { activation [104-109]; } \\
\text { Maintenance of T-cell homeostatic } \\
\text { turnover [128]; } \\
\text { Enhanced suppressive } \\
\text { function [110] }\end{array}$ & $\begin{array}{l}\text { T cells [104,109] } \\
\text { CD4+ T cells [105-108] } \\
\text { CD8+ T cells [128] } \\
\text { regulatory T cells [110] }\end{array}$ & $\begin{array}{c}\text { Mixture [104,105]; } \\
\text { LPC 16:0 > LPC 18:0 > LPC 14:0 > } \\
\text { LPC 18:1 [106]; } \\
\text { LPC 16:0 [107-109]; } \\
\text { LPC 11:0 [128]; } \\
\text { Not listed [110] }\end{array}$ \\
\hline $\begin{array}{l}\text { Increased cytotoxic activity } \\
\text { towards tumor cells [129] }\end{array}$ & NK cells & Not listed [129] \\
\hline $\begin{array}{l}\text { Inhibition of histamine } \\
\text { release [100] }\end{array}$ & mast cells & LPC 16:0 \\
\hline $\begin{array}{c}\text { Increased bactericidal activity } \\
\text { [130], increased reactive oxygen } \\
\text { species (ROS) production [93,131]; } \\
\text { Decreased ROS production [94]; } \\
\text { Inhibition of activation and } \\
\text { effector functions [95] }\end{array}$ & neutrophils (PMNL) & $\begin{array}{c}\text { Mixture [93]; } \\
\text { LPC 18:0 [130]; } \\
\text { Mixture, LPC 14:0, LPC 16:0, LPC } \\
\text { 18:0 [131]; } \\
\text { LPC 16:0, LPC 18:0, LPC 18:1 [94]; } \\
\text { LPC 18:0 [95] }\end{array}$ \\
\hline
\end{tabular}


Table 1. Cont.

\begin{tabular}{ccc}
\hline Function/Action & Tissue/Cell Type Studied & LPC Species Examined \\
\hline $\begin{array}{c}\text { Inhibition of migration and } \\
\text { effector functions [98] }\end{array}$ & eosinophils & LPC 16:0, LPC 18:0 [98] \\
\hline $\begin{array}{c}\text { Tumor cell apoptosis [132]; } \\
\begin{array}{c}\text { Reduction in tumor cell migration } \\
\text { and adhesion [133] }\end{array}\end{array}$ & tumor cells & Mixture [132]; \\
\hline
\end{tabular}

\section{Future Directions of LPC as a Biomarker}

In contrast to older studies, most of the more recent studies using mass spectrometry to quantify LPC subspecies mainly reported that decreased plasma LPC levels are associated with unfavorable disease outcomes. Decreased levels of LPC were observed in rheumatoid arthritis [34], diabetes [35], schizophrenia [36], polycystic ovary syndrome [37,38], Alzheimer disease [39,40], pulmonary arterial hypertension [41], aging [42], asthma [43] and liver cirrhosis, where they were associated with increased mortality risk [44]. Correspondingly serum metabolic profiling of patients undergoing treatment for schizophrenia discovered an increase in LPC following successful pharmacologic intervention [134]. Similarly, plasma LPC levels are decreased in sepsis [135] and correlate inversely with sepsis mortality [136] and in-hospital mortality in pneumonia [137]. Additionally, higher blood concentrations of LPC are positively correlated with the muscle insulin sensitivity index in diabetic patients [138] and inversely correlate with impaired fasting glucose and diabetes incidence [139-142]. Importantly, a reduction in LPCs was associated with a risk of adverse outcome in chronic kidney disease patients [143].

In the context of cancer research decreased levels of certain LPCs were identified as potential biomarkers in colorectal cancer [144-146], hepatocellular carcinoma [147], ovarian cancer [148,149], cholangiocarcinoma [150], pancreatic and biliary tract cancer [151] as well as cervical cancer [152]. Of particular interest, LPC levels proved to correctly predict the recurrence of prostate cancer after surgery [153]. LPC levels are decreased in cancer, associated with weight loss and increased inflammation, where they inversely correlate with CRP levels in plasma [22]. In lung cancer, decreased LPC levels were observed in malignant compared to benign pleural effusion [154]. Furthermore, a prospective metabolomics study discovered that higher levels of saturated LPC 18:0 reduced the risk of most common cancers [155], while higher levels of 8 different LPCs correlated with lower risk of advanced stage prostate cancer [156]. To enable high-throughput and quantitative analysis of LPCs as cancer biomarkers a novel parylene matrix biochip was recently developed and validated for clinical diagnosis [157].

\section{Conclusions}

Research into bioactive LPCs often resulted in contradicting data, even from experiments performed in the same disease model or cell type. Older studies that suggested that LPC could negatively affect many inflammatory diseases led research to look for treatments to lower LPC levels. Plasma levels of sPLA ${ }_{2}$-IIa correlate with cardiovascular risk and it is, therefore, thought to be involved in the pathogenesis of atherosclerosis [158-162]. This assumption suggests that a therapeutic intervention targeting sPLA 2 could lead to favorable therapeutic effects for the patients. Indeed, a large clinical trial using the sPLA 2 inhibitor varespladib (LY315920) targeting sPLA 2 groups IIa, V and $X$ did decrease lipid biomarkers as expected, which theoretically should have translated to a lower propensity to plaque rupture in the 16 weeks following acute coronary syndromes [163]. However, the study was terminated early "for futility" after an interim analysis of the outcomes for only 212 of the 5012 randomized patients [163]. In contrast, the use of varespladib was found to increase the probability of myocardial infarction, stroke and mortality in patients with acute coronary syndrome and acute coronary disease [163]. Moreover, clinical trials using the sPLA ${ }_{2}$ inhibitor varespladib found no evidence of beneficial effects for the treatment and prevention of sickle cell disease (NCT01522196), 
asthma [164], rheumatoid arthritis [165] and acute coronary syndrome [163]. The use of Varespladib was even associated with higher events of the composite primary outcome (cardiovascular mortality, nonfatal myocardial infarction, nonfatal stroke or unstable angina requiring hospitalization) and the trial was terminated for potential harm [163]. Hence, a more unbiased approach is needed to understand LPC in the context of homeostasis and disease pathology.

Possible explanations for the discrepancy of data include use of different LPC species in regards to acyl chain length and saturation, which can impact their biological activity and function as shown by Frank et all in different models [52,59,65]. Since the free form of LPC is biologically most active [18], the results strongly depend on the presence and concentration of carrier proteins such as albumin or on the presence of lipoproteins in the experimental setup. Moreover, it was shown that a lot of reported pro-inflammatory effects attributed to LPC actually arise from PAF-like activity from contaminating phospholipids in some commercial preparations of LPC [166]. When these preparations were submitted to PAF acetylhydrolase or saponification (thereby targeting the susceptible $s n-2$ residue in PAF) the pro-inflammatory activity of the LPC preparations was abolished.

Another important, but often overlooked issue in older studies, is the rapid conversion of LPC in biological fluids, tissue and living cells to phospholipids [167] or to lysophosphatidic acid (LPA) through the action of autotaxin [168]. In fact, LPC is the main substrate for the production of LPA, which is able to signal through $\mathrm{G}$ protein-coupled receptors and is implicated in chronic inflammation, fibrotic diseases and thrombosis $[169,170]$. Of particular interest in this context are recently published studies that link the pro-atherogenic effects of LPC to the effect of LPA on its receptors. It may well be that LPA and not LPC is responsible for the reported effects of LPC and ox-LDL on the development of atherosclerosis. [171-175]. Small molecule inhibitors of autotaxin, a secreted phosphodiesterase that produces LPA from LPC, and thus increasing LPC levels - are a new promising therapeutic option. Autotoxin inhibitors, which are currently entering phase III clinical trials for idiopathic pulmonary fibrosis have been extensively reviewed elsewhere [176]. Results of future studies employing autotaxin inhibitors are eagerly awaited.

When interpreting the available clinical and biomarker data and many newer experimental studies, it is clear that LPCs cannot be described simply as pro-inflammatory mediators, as anti-inflammatory activities often predominate. We therefore suggest that LPCs should instead be recognized as important homeostatic mediators involved in all stages of vascular inflammation through their effect on vascular reactivity, endothelial activation and infiltration, and activation of immune cells. Like with everything in nature it is impossible to paint a completely black and white picture of LPC due to the complexity of its interactions with a plethora of immune cells and its involvement in various processes. Nonetheless, the advancement of methods designed with appropriate controls as well as the use of stable LPC analogues has clearly aided in greater understanding of LPC actions in health and disease.

Author Contributions: Conceptualization, E.K. and G.M.; writing—original draft preparation, E.K.; writing一review and editing, E.K and G.M.; supervision, G.M. All authors have read and agreed to the published version of the manuscript.

Funding: Research was funded by Austrian Science Fund, grant number W1241, DK MOLIN.

Conflicts of Interest: The authors declare no conflict of interest.

\section{Abbreviations}

$\begin{array}{ll}\text { eNOS } & \text { Endothelial Nitric Oxide Synthase } \\ \text { HDL } & \text { High-Density Lipoprotein } \\ \text { LPA } & \text { Lysophosphatidic Acid } \\ \text { LPC } & \text { lysophosphatidylcholine } \\ \text { Ox-LDL } & \text { Oxidized Low-Density Lipoprotein } \\ \text { sPLA }_{2} & \text { Secreted Phospholipase A2 }\end{array}$




\section{References}

1. Kuzell, W.C.; Davison, R.A. Serum lysolecithin in rheumatoid arthritis, pregnancy, and jaundice and in normal persons. J. Lab. Clin. Med. 1946, 31, 1223-1226. [PubMed]

2. Marinetti, G.V.; Erbland, J.; Temple, K.; Stotz, E. Hydrolysis of lecithins by venom phospholipase A. I. Structure of the enzymically formed lysolecithins. Biochim. Biophys. Acta 1960, 38, 524-534. [CrossRef]

3. Sun, C.; Hanasaka, A.; Kashiwagi, H.; Ueno, M. Formation and characterization of phosphatidylethanolamine/lysophosphatidylcholine mixed vesicles. Biochim. Biophys. Acta-Biomembr. 2000, 1467, 18-26. [CrossRef]

4. Mcmahon, H.T.; Boucrot, E. Membrane curvature at a glance. J. Cell Sci. 2015, 128, 1065-1070. [CrossRef] [PubMed]

5. Reman, F.C.; Van Deenen, L.L.M. The action of some synthetic lysolecithins and lecithins on erythrocytes and lipid bilayers. Biochim. Biophys. Acta-Lipids Lipid Metab. 1967, 137, 592-594. [CrossRef]

6. Flavahan, N.A. Lysophosphatidylcholine modifies $G$ protein-dependent signaling in porcine endothelial cells. Am. J. Physiol. Circ. Physiol. 1993, 264, H722-H727. [CrossRef]

7. Okajima, F.; Sato, K.; Tomura, H.; Kuwabara, A.; Nochi, H.; Tamoto, K.; Kondo, Y.; Tokumitsu, Y.; Ui, M. Stimulatory and inhibitory actions of lysophosphatidylcholine, depending on its fatty acid residue, on the phospholipase C/Ca2+ system in HL-60 leukaemia cells. Biochem. J. 1998, 336, 491-500. [CrossRef]

8. Soga, T.; Ohishi, T.; Matsui, T.; Saito, T.; Matsumoto, M.; Takasaki, J.; Matsumoto, S.; Kamohara, M.; Hiyama, H.; Yoshida, S.; et al. Lysophosphatidylcholine enhances glucose-dependent insulin secretion via an orphan G-protein-coupled receptor. Biochem. Biophys. Res. Commun. 2005, 326, 744-751. [CrossRef]

9. Drzazga, A.; Kristinsson, H.; Sałaga, M.; Zatorski, H.; Koziołkiewicz, M.; Gendaszewska-Darmach, E.; Bergsten, P. Lysophosphatidylcholine and its phosphorothioate analogues potentiate insulin secretion via GPR40 (FFAR1), GPR55 and GPR119 receptors in a different manner. Mol. Cell. Endocrinol. 2018, 472, 117-125. [CrossRef]

10. Drzazga, A.; Sowinska, A.; Krzeminska, A.; Rytczak, P.; Koziolkiewicz, M.; Gendaszewska-Darmach, E. Lysophosphatidylcholine elicits intracellular calcium signaling in a GPR55-dependent manner. Biochem. Biophys. Res. Commun. 2017, 489, 242-247. [CrossRef]

11. Zhu, K.; Baudhuin, L.M.; Hong, G.; Williams, F.S.; Cristina, K.L.; Kabarowski, J.H.S.; Witte, O.N.; Xu, Y. Sphingosylphosphorylcholine and Lysophosphatidylcholine Are Ligands for the G Protein-coupled Receptor GPR4. J. Biol. Chem. 2001, 276, 41325-41335. [CrossRef] [PubMed]

12. Kabarowski, J.H.S.; Zhu, K.; Le, L.Q.; Witte, O.N.; Xu, Y. Lysophosphatidylcholine as a Ligand for the Immunoregulatory Receptor G2A. Science 2001, 293, 702-705. [CrossRef]

13. Witte, O.N.; Kabarowski, J.H.; Xu, Y.; Le, L.Q.; Zhu, K. Retraction. Science 2005, 307, 206b. [CrossRef] [PubMed]

14. Ludwig, M.-G.; Vanek, M.; Guerini, D.; Gasser, J.A.; Jones, C.E.; Junker, U.; Hofstetter, H.; Wolf, R.M.; Seuwen, K. Proton-sensing G-protein-coupled receptors. Nature 2003, 425, 93-98. [CrossRef] [PubMed]

15. Sphingosylphosphorylcholine and lysophosphatidylcholine are ligands for the G protein-coupled receptor GPR4. J. Biol. Chem. 2005, 280, 43280.

16. Bektas, M.; Barak, L.S.; Jolly, P.S.; Liu, H.; Lynch, K.R.; Lacana, E.; Suhr, K.-B.; Milstien, S.; Spiegel, S. The G Protein-Coupled Receptor GPR4 Suppresses ERK Activation in a Ligand-Independent Manner ${ }^{\dagger}$. Biochemistry 2003, 42, 12181-12191. [CrossRef] [PubMed]

17. Drzazga, A.; Okulus, M.; Rychlicka, M.; Biegała, Ł.; Gliszczyńska, A.; Gendaszewska-Darmach, E. Lysophosphatidylcholine containing anisic acid is able to stimulate insulin secretion targeting g protein coupled receptors. Nutrients 2020, 12, 1173. [CrossRef]

18. Kim, Y.L.; Im, Y.J.; Ha, N.C.; Im, D.S. Albumin inhibits cytotoxic activity of lysophosphatidylcholine by direct binding. Prostaglandins Other Lipid Mediat. 2007, 83, 130-138. [CrossRef]

19. Gillett, M.P.T.; Besterman, E.M.M. Plasma concentrations of lysolecithin and other phospholipids in the healthy population and in men suffering from atherosclerotic diseases. Atherosclerosis 1975, 22, 111-124. [CrossRef]

20. Switzer, S.; Eder, H.A. Transport of lysolecithin by albumin in human and rat plasma. J. Lipid Res. 1965, 6, 506-511. 
21. Vuong, T.H.I.D.; Stroes, E.S.G.; Willekes-Koolschijn, N.E.L.; Rabelink, T.O.N.J.; Koomans, H.A.; Joles, J.A. Hypoalbuminemia increases lysophosphatidylcholine in low-density lipoprotein of normocholesterolemic subjects. Kidney Int. 1999, 55, 1005-1010. [CrossRef] [PubMed]

22. Taylor, L.A.; Arends, J.; Hodina, A.K.; Unger, C.; Massing, U. Plasma lyso-phosphatidylcholine concentration is decreased in cancer patients with weight loss and activated inflammatory status. Lipids Health Dis. 2007, 6, 17. [CrossRef] [PubMed]

23. Andreoli, V.M.; Maffei, F.; Tonon, G.C.; Zibetti, A. Significance of plasma lysolecithin in patients with multiple sclerosis: A longitudinal study. J. Neurol. Neurosurg. Psychiatry 1973, 36, 661-667. [CrossRef] [PubMed]

24. Joles, J.A.; Willekes-Koolschun, N.; Koons, H.A. Hypoalbuminemia causes high blood viscosity by increasing red cell lysophosphatidylcholine. Kidney Int. 1997, 52, 761-770. [CrossRef]

25. Lauber, K.; Bohn, E.; Kröber, S.M.; Xiao, Y.; Blumenthal, S.G.; Lindemann, R.K.; Marini, P.; Wiedig, C.; Zobywalski, A.; Baksh, S.; et al. Apoptotic Cells Induce Migration of Phagocytes via Caspase-3-Mediated Release of a Lipid Attraction Signal. Cell 2003, 113, 717-730. [CrossRef]

26. Fuchs, B.; Schiller, J. Lysophospholipids: Their generation, physiological role and detection. Are they important disease markers? Mini Rev. Med. Chem. 2009, 9, 368-378. [CrossRef]

27. Rousset, X.; Vaisman, B.; Amar, M.; Sethi, A.A.; Remaley, A.T. Lecithin: Cholesterol acyltransferase-from biochemistry to role in cardiovascular disease. Curr. Opin. Endocrinol. Diabetes. Obes. 2009, 16, 163-171. [CrossRef]

28. Santamarina-Fojo, S.; Gonzaález-Navarro, H.; Freeman, L.; Wagner, E.; Nong, Z. Hepatic Lipase, Lipoprotein Metabolism, and Atherogenesis. Arterioscler. Thromb. Vasc. Biol. 2004, 24, 1750-1754. [CrossRef]

29. Gauster, M.; Rechberger, G.; Sovic, A.; Hörl, G.; Steyrer, E.; Sattler, W.; Frank, S. Endothelial lipase releases saturated and unsaturated fatty acids of high density lipoprotein phosphatidylcholine. J. Lipid Res. 2005, 46, 1517-1525. [CrossRef]

30. Matsumoto, T.; Kobayashi, T.; Kamata, K. Role of Lysophosphatidylcholine (LPC) in Atherosclerosis. Curr. Med. Chem. 2007, 14, 3209-3220. [CrossRef]

31. Seilhamer, J.J.; Pruzanski, W.; Vadas, P.; Plant, S.; Miller, J.A.; Kloss, J.; Johnson, L.K. Cloning and recombinant expression of phospholipase A2 present in rheumatoid arthritic synovial fluid. J. Biol. Chem. 1989, 264, 5335-5338. [PubMed]

32. Murakami, M.; Sato, H.; Miki, Y.; Yamamoto, K.; Taketomi, Y. A new era of secreted phospholipase $\mathrm{A}_{2}$. J. Lipid Res. 2015, 56, 1248-1261. [CrossRef] [PubMed]

33. Hanna, V.S.; Hafez, E.A.A. Synopsis of arachidonic acid metabolism: A review. J. Adv. Res. 2018, 11, $23-32$. [CrossRef] [PubMed]

34. Fuchs, B.; Schiller, J.; Wagner, U.; Häntzschel, H.; Arnold, K. The phosphatidylcholine/lysophosphatidylcholine ratio in human plasma is an indicator of the severity of rheumatoid arthritis: Investigations by 31P NMR and MALDI-TOF MS. Clin. Biochem. 2005, 38, 925-933. [CrossRef] [PubMed]

35. Barber, M.N.; Risis, S.; Yang, C.; Meikle, P.J.; Staples, M.; Febbraio, M.A.; Bruce, C.R. Plasma Lysophosphatidylcholine Levels Are Reduced in Obesity and Type 2 Diabetes. PLoS ONE 2012, 7, e41456. [CrossRef] [PubMed]

36. Wang, D.; Cheng, S.L.; Fei, Q.; Gu, H.; Raftery, D.; Cao, B.; Sun, X.; Yan, J.; Zhang, C.; Wang, J. Metabolic profiling identifies phospholipids as potential serum biomarkers for schizophrenia. Psychiatry Res. 2019, 272, 18-29. [CrossRef]

37. Sun, Z.; Chang, H.M.; Wang, A.; Song, J.; Zhang, X.; Guo, J.; Leung, P.C.K.; Lian, F. Identification of potential metabolic biomarkers of polycystic ovary syndrome in follicular fluid by SWATH mass spectrometry. Reprod. Biol. Endocrinol. 2019, 17, 45. [CrossRef]

38. Jiang, Y.; Qi, J.; Xue, X.; Huang, R.; Zheng, J.; Liu, W.; Yin, H.; Li, S. Ceramide subclasses identified as novel lipid biomarker elevated in women with polycystic ovary syndrome: A pilot study employing shotgun lipidomics. Gynecol. Endocrinol. 2019, 1-5. [CrossRef]

39. Grimm, M.O.W.; Grösgen, S.; Riemenschneider, M.; Tanila, H.; Grimm, H.S.; Hartmann, T. From brain to food: Analysis of phosphatidylcholins, lyso-phosphatidylcholins and phosphatidylcholin-plasmalogens derivates in Alzheimer's disease human post mortem brains and mice model via mass spectrometry. J. Chromatogr. A 2011, 1218, 7713-7722. [CrossRef] 
40. Mulder, C.; Wahlund, L.-O.; Teerlink, T.; Blomberg, M.; Veerhuis, R.; van Kamp, G.J.; Scheltens, P.; Scheffer, P.G. Decreased lysophosphatidylcholine/phosphatidylcholine ratio in cerebrospinal fluid in Alzheimer?s disease. J. Neural Transm. 2003, 110, 949-955. [CrossRef]

41. Chen, C.; Luo, F.; Wu, P.; Huang, Y.; Das, A.; Chen, S.; Chen, J.; Hu, X.; Li, F.; Fang, Z.; et al. Metabolomics reveals metabolite changes of patients with pulmonary arterial hypertension in China. J. Cell. Mol. Med. 2020, 24, 2484-2496. [CrossRef] [PubMed]

42. Semba, R.D.; Zhang, P.; Adelnia, F.; Sun, K.; Gonzalez-Freire, M.; Salem, N.; Brennan, N.; Spencer, R.G.; Fishbein, K.; Khadeer, M.; et al. Low plasma lysophosphatidylcholines are associated with impaired mitochondrial oxidative capacity in adults in the Baltimore Longitudinal Study of Aging. Aging Cell 2019, 18. [CrossRef] [PubMed]

43. Ried, J.S.; Baurecht, H.; Stückler, F.; Krumsiek, J.; Gieger, C.; Heinrich, J.; Kabesch, M.; Prehn, C.; Peters, A.; Rodriguez, E.; et al. Integrative genetic and metabolite profiling analysis suggests altered phosphatidylcholine metabolism in asthma. Allergy Eur. J. Allergy Clin. Immunol. 2013, 68, 629-636. [CrossRef]

44. Krautbauer, S.; Eisinger, K.; Wiest, R.; Liebisch, G.; Buechler, C. Systemic saturated lysophosphatidylcholine is associated with hepatic function in patients with liver cirrhosis. Prostaglandins Other Lipid Mediat. 2016, 124, 27-33. [CrossRef] [PubMed]

45. Gimbrone, M.A.; García-Cardeña, G. Endothelial Cell Dysfunction and the Pathobiology of Atherosclerosis. Circ. Res. 2016, 118, 620-636. [CrossRef] [PubMed]

46. Yokoyama, M.; Hirata, K.; Miyake, R.; Akita, H.; Ishikawa, Y.; Fukuzaki, H. Lysophosphatidylcholine: Essential role in the inhibition of endothelium-dependent vasorelaxation by oxidized low density lipoprotein. Biochem. Biophys. Res. Commun. 1990, 168, 301-308. [CrossRef]

47. Kugiyama, K.; Kerns, S.A.; Morrisett, J.D.; Roberts, R.; Henry, P.D. Impairment of endothelium-dependent arterial relaxation by lysolecithin in modified low-density lipoproteins. Nature 1990, 344, 160-162. [CrossRef]

48. Mahfouz, M.; Kummerow, F. Oxidized low density lipoprotein inhibits prostacyclin generation by rat aorta in vitro: A key role of lysolecithin. Prostaglandins Other Lipid Mediat. 2001, 66, 283-304. [CrossRef]

49. Stoll, L.L.; Oskarsson, H.J.; Spector, A.A. Interaction of lysophosphatidylcholine with aortic endothelial cells. Am. J. Physiol. Circ. Physiol. 1992, 262, H1853-H1860. [CrossRef]

50. Froese, D.E.; McMaster, J.; Man, R.Y.; Choy, P.C.; Kroeger, E.A. Inhibition of endothelium-dependent vascular relaxation by lysophosphatidylcholine: Impact of lysophosphatidylcholine on mechanisms involving endothelium-derived nitric oxide and endothelium derived hyperpolarizing factor. Mol. Cell. Biochem. 1999, 197, 1-6. [CrossRef]

51. Okamoto, Y.; Kawahara, Y.; Yokoyama, M. Inhibition by lysophosphatidylcholine of nitric oxide production in interleukin 1 beta-stimulated vascular smooth muscle cells. Kobe J. Med. Sci. 1998, 44, 169-189. [PubMed]

52. Rao, S.P.; Riederer, M.; Lechleitner, M.; Hermansson, M.; Desoye, G.; Hallström, S.; Graier, W.F.; Frank, S. Acyl Chain-Dependent Effect of Lysophosphatidylcholine on Endothelium-Dependent Vasorelaxation. PLoS ONE 2013, 8, e65155. [CrossRef] [PubMed]

53. Murohara, T.; Kugiyama, K.; Ohgushi, M.; Sugiyama, S.; Ohta, Y.; Yasue, H. LPC in oxidized LDL elicits vasocontraction and inhibits endothelium- dependent relaxation. Am. J. Physiol. Circ. Physiol. 1994, 267, H2441-H2449. [CrossRef] [PubMed]

54. Galle, J.; Mameghani, A.; Bolz, S.-S.; Gambaryan, S.; Görg, M.; Quaschning, T.; Raff, U.; Barth, H.; Seibold, S.; Wanner, C.; et al. Oxidized LDL and its compound lysophosphatidylcholine potentiate AngII-induced vasoconstriction by stimulation of RhoA. J. Am. Soc. Nephrol. 2003, 14, 1471-1479. [CrossRef] [PubMed]

55. Bing, R.J.; Saeed, M. The role of lysolecithin in the relaxation of vascular smooth muscle. Biosci. Rep. 1987, 7, 783-789. [CrossRef] [PubMed]

56. Saito, T.; Wolf, A.; Menon, N.K.; Saeed, M.; Alves, C.; Bing, R.J. Lysolecithins as endothelium-dependent vascular smooth muscle relaxants that differ from endothelium-derived relaxing factor (nitric oxide). Proc. Natl. Acad. Sci. USA 1988, 85, 8246-8250. [CrossRef]

57. Jougasaki, M.; Kugiyama, K.; Saito, Y.; Nakao, K.; Imura, H.; Yasue, H. Suppression of endothelin-1 secretion by lysophosphatidylcholine in oxidized low density lipoprotein in cultured vascular endothelial cells. Circ. Res. 1992, 71, 614-619. [CrossRef]

58. Zembowicz, A.; Jones, S.L.; Wu, K.K. Induction of cyclooxygenase-2 in human umbilical vein endothelial cells by lysophosphatidylcholine. J. Clin. Invest. 1995, 96, 1688-1692. [CrossRef] 
59. Brkić, L.; Riederer, M.; Graier, W.F.; Malli, R.; Frank, S. Acyl chain-dependent effect of lysophosphatidylcholine on cyclooxygenase (COX)-2 expression in endothelial cells. Atherosclerosis 2012, 224, 348-354. [CrossRef]

60. Zembowicz, A.; Tang, J.L.; Wu, K.K. Transcriptional induction of endothelial nitric oxide synthase type III by lysophosphatidylcholine. J. Biol. Chem. 1995, 270, 17006-17010. [CrossRef]

61. Xing, F.; Liu, J.; Mo, Y.; Liu, Z.; Qin, Q.; Wang, J.; Fan, Z.; Long, Y.; Liu, N.; Zhao, K.; et al. Lysophosphatidylcholine up-regulates human endothelial nitric oxide synthase gene transactivity by c-Jun N-terminal kinase signalling pathway. J. Cell. Mol. Med. 2009, 13, 1136-1148. [CrossRef] [PubMed]

62. Gupta, R.M.; Libby, P.; Barton, M. Linking regulation of nitric oxide to endothelin-1: The Yin and Yang of vascular tone in the atherosclerotic plaque. Atherosclerosis 2020, 292, 201-203. [CrossRef] [PubMed]

63. Radulović, S.; Gottschalk, B.; Hörl, G.; Zardoya-Laguardia, P.; Schilcher, I.; Hallström, S.; Vujić, N.; Schmidt, K.; Trieb, M.; Graier, W.F.; et al. Endothelial lipase increases eNOS activating capacity of high-density lipoprotein. Biochim. Biophys. Acta-Mol. Cell Biol. Lipids 2020, 1865. [CrossRef] [PubMed]

64. Schilcher, I.; Ledinski, G.; Radulović, S.; Hallström, S.; Eichmann, T.; Madl, T.; Zhang, F.; Leitinger, G.; Kolb-Lenz, D.; Darnhofer, B.; et al. Endothelial lipase increases antioxidative capacity of high-density lipoprotein. Biochim. Biophys. Acta-Mol. Cell Biol. Lipids 2019, 1864, 1363-1374. [CrossRef]

65. Riederer, M.; Ojala, P.J.; Hrzenjak, A.; Graier, W.F.; Malli, R.; Tritscher, M.; Hermansson, M.; Watzer, B.; Schweer, H.; Desoye, G.; et al. Acyl chain-dependent effect of lysophosphatidylcholine on endothelial prostacyclin production. J. Lipid Res. 2010, 51, 2957-2966. [CrossRef]

66. Wolf, A.; Saito, T.; Menon, N.K.; Zehetgruber, M.; Bing, R.J. Effect of lysophosphatidylcholine on atherosclerotic rabbit arteries. Atherosclerosis 1989, 80, 81-89. [CrossRef]

67. Wolf, A.; Saito, T.; Dudek, R.; Bing, R.J. The effect of lysophosphatidylcholine on coronary and renal circulation in the rabbit. Lipids 1991, 26, 223-226. [CrossRef]

68. Hansson, G.K.; Libby, P. The immune response in atherosclerosis: A double-edged sword. Nat. Rev. Immunol. 2006, 6, 508-519. [CrossRef]

69. Hansson, G.K.; Hermansson, A. The immune system in atherosclerosis. Nat. Immunol. 2011, 12, $204-212$. [CrossRef]

70. Galkina, E.; Ley, K. Immune and Inflammatory Mechanisms of Atherosclerosis. Annu. Rev. Immunol. 2009, 27, 165-197. [CrossRef]

71. Sugiyama, S.; Kugiyama, K.; Ohgushi, M.; Fujimoto, K.; Yasue, H. Lysophosphatidylcholine in oxidized low-density lipoprotein increases endothelial susceptibility to polymorphonuclear leukocyte-induced endothelial dysfunction in porcine coronary arteries. Role of protein kinase C. Circ. Res. 1994, 74, 565-575. [CrossRef] [PubMed]

72. Zhu, Y.; Lin, J.H.; Liao, H.L.; Verna, L.; Stemerman, M.B. Activation of ICAM-1 promoter by lysophosphatidylcholine: Possible involvement of protein tyrosine kinases. Biochim. Biophys. Acta 1997, 1345, 93-98. [CrossRef]

73. Zou, Y.; Kim, C.H.; Chung, J.H.; Kim, J.Y.; Chung, S.W.; Kim, M.K.; Im, D.S.; Lee, J.; Yu, B.P.; Chung, H.Y. Upregulation of endothelial adhesion molecules by lysophosphatidylcholine. FEBS J. 2007, 274, 2573-2584. [CrossRef] [PubMed]

74. Murohara, T.; Scalia, R.; Lefer, A.M. Lysophosphatidylcholine promotes P-selectin expression in platelets and endothelial cells. Possible involvement of protein kinase $\mathrm{C}$ activation and its inhibition by nitric oxide donors. Circ. Res. 1996, 78, 780-789. [CrossRef]

75. Li, X.; Wang, L.; Fang, P.; Sun, Y.; Jiang, X.; Wang, H.; Yang, X.-F. Lysophospholipids induce innate immune transdifferentiation of endothelial cells, resulting in prolonged endothelial activation. J. Biol. Chem. 2018, 293, 11033-11045. [CrossRef]

76. Jing, Q.; Xin, S.M.; Zhang, W.B.; Wang, P.; Qin, Y.W.; Pei, G. Lysophosphatidylcholine activates p38 and p42/44 mitogen-activated protein kinases in monocytic THP-1 cells, but only p38 activation is involved in its stimulated chemotaxis. Circ. Res. 2000, 87, 52-59. [CrossRef]

77. Quinn, M.T.; Parthasarathy, S.; Steinberg, D. Lysophosphatidylcholine: A chemotactic factor for human monocytes and its potential role in atherogenesis. Proc. Natl. Acad. Sci. USA 1988, 85, 2805-2809. [CrossRef]

78. Radu, C.G.; Yang, L.V.; Riedinger, M.; Au, M.; Witte, O.N. T cell chemotaxis to lysophosphatidylcholine through the G2A receptor. Proc. Natl. Acad. Sci. USA 2004, 101, 245-250. [CrossRef] 
79. Jin, Y.; Damaj, B.B.; Maghazachi, A.A. Human resting CD16-, CD16+ and IL-2-, IL-12-, IL-15- or IFN- $\alpha$-activated natural killer cells differentially respond to sphingosylphosphorylcholine, lysophosphatidylcholine and platelet-activating factor. Eur. J. Immunol. 2005, 35, 2699-2708. [CrossRef]

80. Gisterå, A.; Hansson, G.K. The immunology of atherosclerosis. Nat. Rev. Nephrol. 2017, 13, 368-380. [CrossRef]

81. Ngwenya, B.Z.; Yamamoto, N. Activation of peritoneal macrophages by lysophosphatidylcholine. Biochim. Biophys. Acta 1985, 839, 9-15. [CrossRef]

82. Qin, X.; Qiu, C.; Zhao, L. Lysophosphatidylcholine perpetuates macrophage polarization toward classically activated phenotype in inflammation. Cell. Immunol. 2014, 289, 185-190. [CrossRef] [PubMed]

83. Oestvang, J.; Anthonsen, M.W.; Johansen, B. LysoPC and PAF Trigger Arachidonic Acid Release by Divergent Signaling Mechanisms in Monocytes. J. Lipids 2011, 2011, 1-11. [CrossRef] [PubMed]

84. Cha, M.H.; Lee, S.M.; Jung, J. Lysophosphatidylcholine induces expression of genes involved in cholesterol biosynthesis in THP-1 derived macrophages. Steroids 2018, 139, 28-34. [CrossRef] [PubMed]

85. Rolin, J.; Vego, H.; Maghazachi, A. Oxidized Lipids and Lysophosphatidylcholine Induce the Chemotaxis, Up-Regulate the Expression of CCR9 and CXCR4 and Abrogate the Release of IL-6 in Human Monocytes. Toxins (Basel) 2014, 6, 2840-2856. [CrossRef]

86. Hourton, D.; Stengel, D.; Chapman, M.J.; Ninio, E. Oxidized low density lipoproteins downregulate LPS-induced platelet-activating factor receptor expression in human monocyte-derived macrophages: Implications for LPS-induced nuclear factor-kappaB binding activity. Eur. J. Biochem. 2001, 268, 4489-4496. [CrossRef]

87. Carneiro, A.B.; Iaciura, B.M.F.; Nohara, L.L.; Lopes, C.D.; Veas, E.M.C.; Mariano, V.S.; Bozza, P.T.; Lopes, U.G.; Atella, G.C.; Almeida, I.C.; et al. Lysophosphatidylcholine Triggers TLR2- and TLR4-Mediated Signaling Pathways but Counteracts LPS-Induced NO Synthesis in Peritoneal Macrophages by Inhibiting NF- $\mathrm{B}$ Translocation and MAPK/ERK Phosphorylation. PLoS ONE 2013, 8, e76233. [CrossRef]

88. Hara, S.; Shike, T.; Takasu, N.; Mizui, T. Lysophosphatidylcholine promotes cholesterol efflux from mouse macrophage foam cells. Arterioscler. Thromb. Vasc. Biol. 1997, 17, 1258-1266. [CrossRef]

89. Hou, M.; Xia, M.; Zhu, H.; Wang, Q.; Li, Y.; Xiao, Y.; Zhao, T.; Tang, Z.; Ma, J.; Ling, W. Lysophosphatidylcholine promotes cholesterol efflux from mouse macrophage foam cells via PPAR $\gamma$-LXR $\alpha$-ABCA1-dependent pathway associated with apoE. Cell Biochem. Funct. 2007, 25, 33-44. [CrossRef]

90. O'Neil, L.J.; Kaplan, M.J.; Carmona-Rivera, C. The Role of Neutrophils and Neutrophil Extracellular Traps in Vascular Damage in Systemic Lupus Erythematosus. J. Clin. Med. 2019, 8, 1325. [CrossRef]

91. Bot, I.; Shi, G.P.; Kovanen, P.T. Mast cells as effectors in atherosclerosis. Arterioscler. Thromb. Vasc. Biol. 2015, 35, 265-271. [CrossRef] [PubMed]

92. Marx, C.; Novotny, J.; Salbeck, D.; Zellner, K.R.; Nicolai, L.; Pekayvaz, K.; Kilani, B.; Stockhausen, S.; Bürgener, N.; Kupka, D.; et al. Eosinophil-platelet interactions promote atherosclerosis and stabilize thrombosis with eosinophil extracellular traps. Blood 2019, 134, 1859-1872. [CrossRef]

93. Englberger, W.; Bitter-Suermann, D.; Hadding, U. Influence of lysophospholipids and PAF on the oxidative burst of PMNL. Int. J. Immunopharmacol. 1987, 9, 275-282. [CrossRef]

94. Lin, P.; Welch, E.J.; Gao, X.-P.; Malik, A.B.; Ye, R.D. Lysophosphatidylcholine modulates neutrophil oxidant production through elevation of cyclic AMP. J. Immunol. 2005, 174, 2981-2989. [CrossRef] [PubMed]

95. Curcic, S.; Holzer, M.; Frei, R.; Pasterk, L.; Schicho, R.; Heinemann, A.; Marsche, G. Neutrophil effector responses are suppressed by secretory phospholipase A2 modified HDL. Biochim. Biophys. Acta 2015, 1851, 184-193. [CrossRef]

96. Nishiyama, O.; Kume, H.; Kondo, M.; Ito, Y.; Ito, M.; Yamaki, K. Role of lysophosphatidylcholine in eosinophil infiltration and resistance in airways. Clin. Exp. Pharmacol. Physiol. 2004, 31, 179-184. [CrossRef] [PubMed]

97. Zhu, X.; Learoyd, J.; Butt, S.; Zhu, L.; Usatyuk, P.V.; Natarajan, V.; Munoz, N.M.; Leff, A.R. Regulation of eosinophil adhesion by lysophosphatidylcholine via a non-store-operated Ca2+ channel. Am. J. Respir. Cell Mol. Biol. 2007, 36, 585-593. [CrossRef]

98. Knuplez, E.; Curcic, S.; Theiler, A.; Bärnthaler, T.; Trakaki, A.; Trieb, M.; Holzer, M.; Heinemann, A.; Zimmermann, R.; Sturm, E.M.; et al. Lysophosphatidylcholines inhibit human eosinophil activation and suppress eosinophil migration in vivo. Biochim. Biophys. Acta-Mol. Cell Biol. Lipids 2020, 1865, 158686. [CrossRef] 
99. Marquardt, D.L.; Walker, L.L. Lysophosphatidylcholine induces mast cell secretion and protein kinase C activation. J. Allergy Clin. Immunol. 1991, 88, 721-730. [CrossRef]

100. Mio, M.; Ikeda, A.; Akagi, M.; Tasaka, K. Inhibitory effect of lysophosphatidylcholine on the histamine release from rat peritoneal mast cells. Agents Actions 1985, 16, 113-117. [CrossRef]

101. Hansson, G.K.; Libby, P.; Schönbeck, U.; Yan, Z.Q. Innate and adaptive immunity in the pathogenesis of atherosclerosis. Circ. Res. 2002, 91, 281-291. [CrossRef] [PubMed]

102. Stemme, S.; Faber, B.; Holm, J.; Wiklund, O.; Witztum, J.L.; Hansson, G.K. T lymphocytes from human atherosclerotic plaques recognize oxidized low density lipoprotein. Proc. Natl. Acad. Sci. USA 1995, 92, 3893-3897. [CrossRef] [PubMed]

103. Paulsson, G.; Zhou, X.; Törnquist, E.; Hansson, G.K. Oligoclonal T cell expansions in atherosclerotic lesions of apolipoprotein E-deficient mice. Arterioscler. Thromb. Vasc. Biol. 2000, 20, 10-17. [CrossRef] [PubMed]

104. Asaoka, Y.; Oka, M.; Yoshida, K.; Sasaki, Y.; Nishizuka, Y. Role of lysophosphatidylcholine in T-lymphocyte activation: Involvement of phospholipase A2 in signal transduction through protein kinase C. Proc. Natl. Acad. Sci. USA 1992, 89, 6447-6451. [CrossRef] [PubMed]

105. Hara, Y.; Kusumi, Y.; Mitsumata, M.; Li, X.-K.; Fujino, M. Lysophosphatidylcholine upregulates LOX-1, chemokine receptors, and activation-related transcription factors in human T-cell line Jurkat. J. Thromb. Thrombolysis 2008, 26, 113-118. [CrossRef]

106. Im, Y.; Lee, Y.; Chung, H.; Im, D. Multiple actions of lysophosphatidylcholine in human Jurkat T cells1. Acta Pharmacol. Sin. 2006, 27, 700-707. [CrossRef]

107. Sakata-Kaneko, S.; Wakatsuki, Y.; Usui, T.; Matsunaga, Y.; Itoh, T.; Nishi, E.; Kume, N.; Kita, T. Lysophosphatidylcholine upregulates CD40 ligand expression in newly activated human CD4+ T cells. FEBS Lett. 1998, 433, 161-165. [CrossRef]

108. Han, K.H.; Hong, K.H.; Ko, J.; Rhee, K.S.; Hong, M.K.; Kim, J.J.; Kim, Y.H.; Park, S.J. Lysophosphatidylcholine up-regulates CXCR4 chemokine receptor expression in human CD4 T cells. J. Leukoc. Biol. 2004, 76, 195-202. [CrossRef]

109. Nishi, E.; Kume, N.; Ueno, Y.; Ochi, H.; Moriwaki, H.; Kita, T. Lysophosphatidylcholine enhances cytokine-induced interferon gamma expression in human T lymphocytes. Circ. Res. 1998, 83, 508-515. [CrossRef]

110. Hasegawa, H.; Lei, J.; Matsumoto, T.; Onishi, S.; Suemori, K.; Yasukawa, M. Lysophosphatidylcholine enhances the suppressive function of human naturally occurring regulatory $\mathrm{T}$ cells through TGF- $\beta$ production. Biochem. Biophys. Res. Commun. 2011, 415, 526-531. [CrossRef]

111. Ait-Oufella, H.; Salomon, B.L.; Potteaux, S.; Robertson, A.K.L.; Gourdy, P.; Zoll, J.; Merval, R.; Esposito, B.; Cohen, J.L.; Fisson, S.; et al. Natural regulatory T cells control the development of atherosclerosis in mice. Nat. Med. 2006, 12, 178-180. [CrossRef] [PubMed]

112. Mor, A.; Planer, D.; Luboshits, G.; Afek, A.; Metzger, S.; Chajek-Shaul, T.; Keren, G.; George, J. Role of naturally occurring CD4+CD25+ regulatory T cells in experimental atherosclerosis. Arterioscler. Thromb. Vasc. Biol. 2007, 27, 893-900. [CrossRef] [PubMed]

113. Grainger, D.J.; Kemp, P.R.; Metcalfe, J.C.; Liu, A.C.; Lawn, R.M.; Williams, N.R.; Grace, A.A.; Schofield, P.M.; Chauhan, A. The serum concentration of active transforming growth factor- $\beta$ is severely depressed in advanced atherosclerosis. Nat. Med. 1995, 1, 74-79. [CrossRef] [PubMed]

114. Mallat, Z.; Gojova, A.; Marchiol-Fournigault, C.; Esposito, B.; Kamaté, C.; Merval, R.; Fradelizi, D.; Tedgui, A. Inhibition of transforming growth factor- $\beta$ signaling accelerates atherosclerosis and induces an unstable plaque phenotype in mice. Circ. Res. 2001, 89, 930-934. [CrossRef]

115. Nording, H.M.; Seizer, P.; Langer, H.F. Platelets in inflammation and atherogenesis. Front. Immunol. 2015, 6, 98. [CrossRef]

116. Weber, C. Platelets and chemokines in atherosclerosis: Partners in crime. Circ. Res. 2005, 96, 612-616. [CrossRef]

117. Kirschmann, C.; Aloof, S.; Devries, A. Action of Lysolecithin on Blood Platelets. Thromb. Diath. Haemorrh. 1963, 18, 512-524. [CrossRef]

118. Yuan, Y.; Jackson, S.P.; Newnham, H.H.; Mitchell, C.A.; Salem, H.H. An essential role for lysophosphatidylcholine in the inhibition of platelet aggregation by secretory phospholipase A2. Blood 1995, 86, 4166-4174. [CrossRef] 
119. Curcic, S.; Holzer, M.; Pasterk, L.; Knuplez, E.; Eichmann, T.O.; Frank, S.; Zimmermann, R.; Schicho, R.; Heinemann, A.; Marsche, G. Secretory phospholipase A2 modified HDL rapidly and potently suppresses platelet activation. Sci. Rep. 2017, 7, 8030. [CrossRef]

120. Revel-Vilk, S.; Rand, M.L.; Israels, S.J. Primary and Secondary Hemostasis, Regulators of Coagulation, and Fibrinolysis: Understanding the Basics. In SickKids Handbook of Pediatric Thrombosis and Hemostasis; KARGER: Basel, Switzerland, 2013; pp. 5-13.

121. Engelmann, B.; Zieseniss, S.; Brand, K.; Page, S.; Lentschat, A.; Ulmer, A.J.; Gerlach, E. Tissue factor expression of human monocytes is suppressed by lysophosphatidylcholine. Arterioscler. Thromb. Vasc. Biol. 1999, 19, 47-53. [CrossRef]

122. Yamamoto, M.; Hara, H.; Adachi, T. The expression of extracellular-superoxide dismutase is increased by lysophosphatidylcholine in human monocytic U937 cells. Atherosclerosis 2002, 163, 223-228. [CrossRef]

123. Mendonça, M.C.; Rezende, A.; Doi, S.Q.; Sellitti, D.F. Lysophosphatidylcholine increases C-type natriuretic peptide expression in human vascular smooth muscle cells via membrane distortion. Vascul. Pharmacol. 2009, 51, 29-36. [CrossRef] [PubMed]

124. Chang, M.-K.; Hartvigsen, K.; Ryu, J.; Kim, Y.; Han, K. The pro-atherogenic effects of macrophages are reduced upon formation of a complex between C-reactive protein and lysophosphatidylcholine. J. Inflamm. 2012, 9, 42. [CrossRef] [PubMed]

125. Kim, J.-M.; Han, H.-J.; Hur, Y.-H.; Quan, H.; Kwak, S.-H.; Choi, J.-I.; Bae, H.-B. Stearoyl lysophosphatidylcholine prevents lipopolysaccharide-induced extracellular release of high mobility group box-1 through AMP-activated protein kinase activation. Int. Immunopharmacol. 2015, 28, 540-545. [CrossRef]

126. Coutant, F.; Perrin-Cocon, L.; Agaugué, S.; Delair, T.; André, P.; Lotteau, V. Mature dendritic cell generation promoted by lysophosphatidylcholine. J. Immunol. 2002, 169, 1688-1695. [CrossRef]

127. Bühligen, J.; Himmel, M.; Gebhardt, C.; Simon, J.C.; Ziegler, W.; Averbeck, M. Lysophosphatidylcholine-mediated functional inactivation of syndecan-4 results in decreased adhesion and motility of dendritic cells. J. Cell. Physiol. 2010, 225, 905-914. [CrossRef]

128. Piccirillo, A.R.; Hyzny, E.J.; Beppu, L.Y.; Menk, A.V.; Wallace, C.T.; Hawse, W.F.; Buechel, H.M.; Wong, B.H.; Foo, J.C.; Cazenave-Gassiot, A.; et al. The Lysophosphatidylcholine Transporter MFSD2A Is Essential for CD8 + Memory T Cell Maintenance and Secondary Response to Infection. J. Immunol. 2019, 203, 117-126. [CrossRef]

129. Whalen, M.M.; Doshi, R.N.; Bader, B.W.; Bankhurst, A.D. Lysophosphatidylcholine and Arachidonic Acid Are Required in the Cytotoxic Response of Human Natural Killer Cells to Tumor Target Cells. Cell. Physiol. Biochem. 1999, 9, 297-309. [CrossRef]

130. Hong, C.W.; Kim, T.K.; Ham, H.Y.; Nam, J.S.; Kim, Y.H.; Zheng, H.; Pang, B.; Min, T.K.; Jung, J.S.; Lee, S.N.; et al. Lysophosphatidylcholine Increases Neutrophil Bactericidal Activity by Enhancement of Azurophil Granule-Phagosome Fusion via Glycine\{middle dot\}GlyR 2/TRPM2/p38 MAPK Signaling. J. Immunol. 2010, 184, 4401-4413. [CrossRef]

131. Ginsburg, I.; Ward, P.A.; Varani, J. Lysophosphatides enhance superoxide responses of stimulated human neutrophils. Inflammation 1989, 13, 163-174. [CrossRef]

132. Butterworth, A.E.; Cater, D.B. Effect of lysolecithin on the oxygen uptake of tumour cells, polymorphonuclear leucocytes, lymphocytes and macrophages in vitro. Br. J. Cancer 1967, 21, 373-389. [CrossRef] [PubMed]

133. Ross, T.; Heuter, S.; Schlesinger, M.; Jakubzig, B.; Raynor, A.; Massing, U.; Bendas, G. Lysophosphatidylcholine attenuates melanoma cell adhesion and migration dependent on the degree of fatty acid saturation. Int. J. Clin. Pharmacol. Ther. 2015, 53, 1049-1051. [CrossRef] [PubMed]

134. Cao, B.; Jin, M.; Brietzke, E.; McIntyre, R.S.; Wang, D.; Rosenblat, J.D.; Ragguett, R.M.; Zhang, C.; Sun, X.; Rong, C.; et al. Serum metabolic profiling using small molecular water-soluble metabolites in individuals with schizophrenia: A longitudinal study using a pre-post-treatment design. Psychiatry Clin. Neurosci. 2019, 73, 100-108. [CrossRef]

135. Park, D.W.; Kwak, D.S.; Park, Y.Y.; Chang, Y.; Huh, J.W.; Lim, C.-M.; Koh, Y.; Song, D.-K.; Hong, S.-B. Impact of serial measurements of lysophosphatidylcholine on 28-day mortality prediction in patients admitted to the intensive care unit with severe sepsis or septic shock. J. Crit. Care 2014, 29, 882.e5-882.e11. [CrossRef] [PubMed] 
136. Drobnik, W.; Liebisch, G.; Audebert, F.-X.; Fröhlich, D.; Glück, T.; Vogel, P.; Rothe, G.; Schmitz, G. Plasma ceramide and lysophosphatidylcholine inversely correlate with mortality in sepsis patients. J. Lipid Res. 2003, 44, 754-761. [CrossRef]

137. Cho, W.H.; Yeo, H.J.; Yoon, S.H.; Lee, S.E.; Jeon, D.S.; Kim, Y.S.; Lee, S.J.; Jo, E.J.; Mok, J.H.; Kim, M.H.; et al. Lysophosphatidylcholine as a prognostic marker in community-acquired pneumonia requiring hospitalization: A pilot study. Eur. J. Clin. Microbiol. Infect. Dis. 2015, 34, 309-315. [CrossRef] [PubMed]

138. Van der Kolk, B.W.; Vogelzangs, N.; Jocken, J.W.E.; Valsesia, A.; Hankemeier, T.; Astrup, A.; Saris, W.H.M.; Arts, I.C.W.; van Greevenbroek, M.M.J.; Blaak, E.E. Plasma lipid profiling of tissue-specific insulin resistance in human obesity. Int. J. Obes. 2019, 43, 989-998. [CrossRef]

139. Wang, S.; Yu, X.; Zhang, W.; Ji, F.; Wang, M.; Yang, R.; Li, H.; Chen, W.; Dong, J. Association of serum metabolites with impaired fasting glucose/diabetes and traditional risk factors for metabolic disease in Chinese adults. Clin. Chim. Acta 2018, 487, 60-65. [CrossRef]

140. Razquin, C.; Toledo, E.; Clish, C.B.; Ruiz-Canela, M.; Dennis, C.; Corella, D.; Papandreou, C.; Ros, E.; Estruch, R.; Guasch-Ferré, M.; et al. Plasma lipidomic profiling and risk of type 2 diabetes in the PREDIMED trial. Diabetes Care 2018, 41, 2617-2624. [CrossRef]

141. Zeng, Y.; Mtintsilana, A.; Goedecke, J.H.; Micklesfield, L.K.; Olsson, T.; Chorell, E. Alterations in the metabolism of phospholipids, bile acids and branched-chain amino acids predicts development of type 2 diabetes in black South African women: A prospective cohort study. Metabolism. 2019, 95, 57-64. [CrossRef]

142. Diamanti, K.; Cavalli, M.; Pan, G.; Pereira, M.J.; Kumar, C.; Skrtic, S.; Grabherr, M.; Risérus, U.; Eriksson, J.W.; Komorowski, J.; et al. Intra- and inter-individual metabolic profiling highlights carnitine and lysophosphatidylcholine pathways as key molecular defects in type 2 diabetes. Sci. Rep. 2019, 9, 9653. [CrossRef] [PubMed]

143. Duranton, F.; Laget, J.; Gayrard, N.; Saulnier-Blache, J.S.; Lundin, U.; Schanstra, J.P.; Mischak, H.; Weinberger, K.M.; Servel, M.F.; Argilés, A. The CKD plasma lipidome varies with disease severity and outcome. J. Clin. Lipidol. 2019, 13, 176-185. [CrossRef] [PubMed]

144. Shen, S.; Yang, L.; Li, L.; Bai, Y.; Cai, C.; Liu, H. A plasma lipidomics strategy reveals perturbed lipid metabolic pathways and potential lipid biomarkers of human colorectal cancer. J. Chromatogr. B 2017, 1068-1069, 41-48. [CrossRef] [PubMed]

145. Zhao, Z.; Xiao, Y.; Elson, P.; Tan, H.; Plummer, S.J.; Berk, M.; Aung, P.P.; Lavery, I.C.; Achkar, J.P.; Li, L.; et al. Plasma Lysophosphatidylcholine Levels: Potential Biomarkers for Colorectal Cancer. J. Clin. Oncol. 2007, 25, 2696-2701. [CrossRef]

146. Geijsen, A.J.M.R.; van Roekel, E.H.; van Duijnhoven, F.J.B.; Achaintre, D.; Bachleitner-Hofmann, T.; Baierl, A.; Bergmann, M.M.; Boehm, J.; Bours, M.J.L.; Brenner, H.; et al. Plasma metabolites associated with colorectal cancer stage: Findings from an international consortium. Int. J. Cancer 2020, 146, 3256-3266. [CrossRef]

147. Patterson, A.D.; Maurhofer, O.; Beyoglu, D.; Lanz, C.; Krausz, K.W.; Pabst, T.; Gonzalez, F.J.; Dufour, J.-F.; Idle, J.R. Aberrant Lipid Metabolism in Hepatocellular Carcinoma Revealed by Plasma Metabolomics and Lipid Profiling. Cancer Res. 2011, 71, 6590-6600. [CrossRef]

148. Sutphen, R.; Xu, Y.; Wilbanks, G.D.; Fiorica, J.; Grendys, E.C.; LaPolla, J.P.; Arango, H.; Hoffman, M.S.; Martino, M.; Wakeley, K.; et al. Lysophospholipids are potential biomarkers of ovarian cancer. Cancer Epidemiol. Biomarkers Prev. 2004, 13, 1185-1191.

149. Yagi, T.; Kuschner, C.E.; Shoaib, M.; Choudhary, R.C.; Becker, L.B.; Lee, A.T.; Kim, J. Relative ratios enhance the diagnostic power of phospholipids in distinguishing benign and cancerous ovarian masses. Cancers (Basel) 2020, 12, 72. [CrossRef]

150. Kim, K.-H.; Joo, J.; Park, B.; Park, S.-J.; Lee, W.J.; Han, S.-S.; Kim, T.H.; Hong, E.K.; Woo, S.M.; Yoo, B.C. Reduced levels of N'-methyl-2-pyridone-5-carboxamide and lysophosphatidylcholine 16:0 in the serum of patients with intrahepatic cholangiocarcinoma, and the correlation with recurrence-free survival. Oncotarget 2017, 8, 112598-112609. [CrossRef]

151. Lee, J.H.; Yu, S.E.; Kim, K.H.; Yu, M.H.; Jeong, I.H.; Cho, J.Y.; Park, S.J.; Lee, W.J.; Han, S.S.; Kim, T.H.; et al. Individualized metabolic profiling stratifies pancreatic and biliary tract cancer: A useful tool for innovative screening programs and predictive strategies in healthcare. EPMA J. 2018, 9, 287-297. [CrossRef]

152. Yin, M.; Tan, S.; Li, X.; Hou, Y.; Cao, G.; Li, K.; Kou, J.; Lou, G. Identification of phosphatidylcholine and lysophosphatidylcholine as novel biomarkers for cervical cancers in a prospective cohort study. Tumor Biol. 2016, 37, 5485-5492. [CrossRef] 
153. Goto, T.; Terada, N.; Inoue, T.; Kobayashi, T.; Nakayama, K.; Okada, Y.; Yoshikawa, T.; Miyazaki, Y.; Uegaki, M.; Utsunomiya, N.; et al. Decreased expression of lysophosphatidylcholine (16:0/OH) in high resolution imaging mass spectrometry independently predicts biochemical recurrence after surgical treatment for prostate cancer. Prostate 2015, 75, 1821-1830. [CrossRef] [PubMed]

154. Yang, Z.; Song, Z.; Chen, Z.; Guo, Z.; Jin, H.; Ding, C.; Hong, Y.; Cai, Z. Metabolic and lipidomic characterization of malignant pleural effusion in human lung cancer. J. Pharm. Biomed. Anal. 2020, 180. [CrossRef] [PubMed]

155. Kühn, T.; Floegel, A.; Sookthai, D.; Johnson, T.; Rolle-Kampczyk, U.; Otto, W.; von Bergen, M.; Boeing, H.; Kaaks, R. Higher plasma levels of lysophosphatidylcholine 18:0 are related to a lower risk of common cancers in a prospective metabolomics study. BMC Med. 2016, 14, 13. [CrossRef] [PubMed]

156. Schmidt, J.A.; Fensom, G.K.; Rinaldi, S.; Scalbert, A.; Appleby, P.N.; Achaintre, D.; Gicquiau, A.; Gunter, M.J.; Ferrari, P.; Kaaks, R.; et al. Patterns in metabolite profile are associated with risk of more aggressive prostate cancer: A prospective study of 3,057 matched case-control sets from EPIC. Int. J. Cancer 2020, 146, 720-730. [CrossRef] [PubMed]

157. Park, J.-M.; Kim, M.-J.; Noh, J.-Y.; Yun, T.G.; Kang, M.-J.; Lee, S.-G.; Yoo, B.C.; Pyun, J.-C. Simultaneous Analysis of Multiple Cancer Biomarkers Using MALDI-TOF Mass Spectrometry Based on a Parylene-Matrix Chip. J. Am. Soc. Mass Spectrom. 2020, 31, 917-926. [CrossRef] [PubMed]

158. Ivandic, B.; Castellani, L.W.; Wang, X.P.; Qiao, J.H.; Mehrabian, M.; Navab, M.; Fogelman, A.M.; Grass, D.S.; Swanson, M.E.; de Beer, M.C.; et al. Role of group II secretory phospholipase A2 in atherosclerosis: 1. Increased atherogenesis and altered lipoproteins in transgenic mice expressing group IIa phospholipase A2. Arterioscler. Thromb. Vasc. Biol. 1999, 19, 1284-1290. [CrossRef]

159. Hartford, M.; Wiklund, O.; Hultén, L.M.; Perers, E.; Person, A.; Herlitz, J.; Hurt-Camejo, E.; Karlsson, T.; Caidahl, K. CRP, interleukin-6, secretory phospholipase A2 group IIA, and intercellular adhesion molecule-1 during the early phase of acute coronary syndromes and long-term follow-up. Int. J. Cardiol. 2006, 108, 55-62. [CrossRef]

160. Akinkuolie, A.O.; Lawler, P.R.; Chu, A.Y.; Caulfield, M.; Mu, J.; Ding, B.; Nyberg, F.; Glynn, R.J.; Ridker, P.M.; Hurt-Camejo, E.; et al. Group IIA Secretory Phospholipase A2, Vascular Inflammation, and Incident Cardiovascular Disease: An Analysis from the JUPITER Trial. Arterioscler. Thromb. Vasc. Biol. 2019, 39, 1182-1190. [CrossRef]

161. Ghesquiere, S.A.I.; Gijbels, M.J.J.; Anthonsen, M.; Van Gorp, P.J.J.; Van Der Made, I.; Johansen, B.; Hofker, M.H.; De Winther, M.P.J. Macrophage-specific overexpression of group IIa sPLA2 increases atherosclerosis and enhances collagen deposition. J. Lipid Res. 2005, 46, 201-210. [CrossRef]

162. Koenig, W.; Khuseyinova, N. Lipoprotein-associated and secretory phospholipase A2 in cardiovascular disease: The epidemiological evidence. Cardiovasc. Drugs Ther. 2009, 23, 85-92. [CrossRef] [PubMed]

163. Nicholls, S.J.; Kastelein, J.J.P.; Schwartz, G.G.; Bash, D.; Rosenson, R.S.; Cavender, M.A.; Brennan, D.M.; Koenig, W.; Jukema, J.W.; Nambi, V.; et al. Varespladib and Cardiovascular Events in Patients With an Acute Coronary Syndrome. JAMA 2014, 311, 252. [CrossRef] [PubMed]

164. Bowton, D.L.; Dmitrienko, A.A.; Israel, E.; Zeiher, B.G.; Sides, G.D. Impact of a soluble phospholipase A2 inhibitor on inhaled allergen challenge in subjects with asthma. J. Asthma 2005, 42, 65-71. [CrossRef]

165. Bradley, J.D.; Dmitrienko, A.A.; Kivitz, A.J.; Gluck, O.S.; Weaver, A.L.; Wiesenhutter, C.; Myers, S.L.; Sides, G.D. A randomized, double-blinded, placebo-controlled clinical trial of LY333013, a selective inhibitor of group II secretory phospholipase A2, in the treatment of rheumatoid arthritis. J. Rheumatol. 2005, 32, 417-423. [PubMed]

166. Marathe, G.K.; Silva, A.R.; de Castro Faria Neto, H.C.; Tjoelker, L.W.; Prescott, S.M.; Zimmerman, G.A.; McIntyre, T.M. Lysophosphatidylcholine and lyso-PAF display PAF-like activity derived from contaminating phospholipids. J. Lipid Res. 2001, 42, 1430-1437.

167. Besterman, J.M.; Domanico, P.L. Association and metabolism of exogenously-derived lysophosphatidylcholine by cultured mammalian cells: Kinetics and mechanisms. Biochemistry 1992, 31, 2046-2056. [CrossRef]

168. Law, S.H.; Chan, M.L.; Marathe, G.K.; Parveen, F.; Chen, C.H.; Ke, L.Y. An updated review of lysophosphatidylcholine metabolism in human diseases. Int. J. Mol. Sci. 2019, 20, 1149. [CrossRef]

169. Perrakis, A.; Moolenaar, W.H. Autotaxin: Structure-function and signaling. J. Lipid Res. 2014, 55, 1010-1018. [CrossRef] 
170. Barbayianni, E.; Magrioti, V.; Moutevelis-Minakakis, P.; Kokotos, G. Autotaxin inhibitors: A patent review. Expert Opin. Ther. Pat. 2013, 23, 1123-1132. [CrossRef]

171. Bao, L.; Qi, J.; Wang, Y.; Xi, Q.; Tserennadmid, T.; Zhao, P.; Qi, J.; Damirin, A. The atherogenic actions of LPC on vascular smooth muscle cells and its LPA receptor mediated mechanism. Biochem. Biophys. Res. Commun. 2018, 503, 1911-1918. [CrossRef]

172. Chen, L.; Zhang, J.; Deng, X.; Liu, Y.; Yang, X.; Wu, Q.; Yu, C. Lysophosphatidic acid directly induces macrophage-derived foam cell formation by blocking the expression of SRBI. Biochem. Biophys. Res. Commun. 2017, 491, 587-594. [CrossRef] [PubMed]

173. Shen, X.; Zou, J.; Li, F.; Zhang, T.; Guo, T. Lysophosphatidic acid enhances neointimal hyperplasia following vascular injury through modulating proliferation, autophagy, inflammation and oxidative stress. Mol. Med. Rep. 2018, 18, 87-96. [CrossRef] [PubMed]

174. Zhou, Z.; Yang, B.; Li, X.; Liu, H.; Lei, G. Lysophosphatidic Acid Promotes Expression and Activation of Matrix Metalloproteinase 9 (MMP9) in THP-1 Cells via Toll-Like Receptor 4/Nuclear Factor-kB (TLR4/NF-kB) Signaling Pathway. Med. Sci. Monit. 2018, 24, 4861-4868. [CrossRef] [PubMed]

175. Aldi, S.; Matic, L.P.; Hamm, G.; van Keulen, D.; Tempel, D.; Holmstrøm, K.; Szwajda, A.; Nielsen, B.S.; Emilsson, V.; Ait-Belkacem, R.; et al. Integrated Human Evaluation of the Lysophosphatidic Acid Pathway as a Novel Therapeutic Target in Atherosclerosis. Mol. Ther.-Methods Clin. Dev. 2018, 10, 17-28. [CrossRef] [PubMed]

176. Matralis, A.N.; Afantitis, A.; Aidinis, V. Development and therapeutic potential of autotaxin small molecule inhibitors: From bench to advanced clinical trials. Med. Res. Rev. 2018, 39, 976-1013. [CrossRef]

(C) 2020 by the authors. Licensee MDPI, Basel, Switzerland. This article is an open access article distributed under the terms and conditions of the Creative Commons Attribution (CC BY) license (http://creativecommons.org/licenses/by/4.0/). 